\title{
Purification and Characterization of Fe-Containing Superoxide Dismutase from Methanobrevibacter arboriphilus Strain AZ
}

\author{
A. L. Brioukhanov ${ }^{1,2 *}$, V. J. Nesatyy ${ }^{2}$, and A. I. Netrusov ${ }^{1}$ \\ ${ }^{1}$ Department of Microbiology, Faculty of Biology, Lomonosov Moscow State University, \\ 119992 Moscow, Russia; fax: (495) 939-2763; E-mail: brjuchanov@mail.ru \\ ${ }^{2}$ Department of Environmental Toxicology, Swiss Federal Institute of Aquatic Science and Technology (EAWAG), \\ Dübendorf CH-8600, Switzerland
}

Received March 15, 2005

\begin{abstract}
Superoxide dismutase (SOD) was purified from cells of the strict anaerobic methanogenic archaeon Methanobrevibacter arboriphilus strain AZ. The four-step purification procedure resulted in enzyme with specific activity of 3970 units $/ \mathrm{mg}$ and yield of $22 \%$. It was shown that the SOD is a Fe-containing homotetramer composed of subunits of $21.2 \mathrm{kD}$ each. Sodium azide (13.5 mM), unlike KCN, inhibits the activity of the SOD. Hydrogen peroxide $(0.5 \mathrm{mM})$ inactivates the enzyme, which is consistent with the properties of the known Fe-containing SODs from methanogenic Archaea.
\end{abstract}

DOI: $10.1134 /$ S0006297906040134

Key words: superoxide dismutase (SOD), Methanobrevibacter, methanogenic Archaea, anaerobes

Methanogenic Archaea are ancient microorganisms that retain many features of their ancestors and exist under extreme conditions of severe anaerobiosis. However, in spite of their inability to produce $\mathrm{CH}_{4}$ in the presence of oxygen, they are capable of existing in the presence of oxygen for a short time. Methanobrevibacter arboriphilus and Methanobacterium thermoautotrophicum were shown to maintain their vitality under aerobic conditions for several hours [1]. In the case of Methanosarcina barkeri, this period was more than $24 \mathrm{~h}$, this being due to the formation of cell clots [1]. The representatives of Methanobrevibacter isolated from the intestine of the termite Reticulitermes flavipes [2] and from rotting core of trees [3], where aerobic microzones exist, are rather tolerant towards $\mathrm{O}_{2}$. The methanogens Methanogenium, Methanobacterium, and Methanosarcina were found in such an aerobic ecosystem as the surface of vegetables [4]. It has now been proved that the methanogens are capable of living in places where aerobic conditions arise transitorily, such as periodically drained rice-fields [1, 5], sludge sediments in shallows [1], and even aerobic desert soils [6]. Methanogenesis is possible in the presence of $\mathrm{O}_{2}$ in the associations of strictly anaerobic methanogens and facultative anaerobes consuming $\mathrm{O}_{2}$ [7].

* To whom correspondence should be addressed.
To provide defense against the toxic effects of products of incomplete reduction of oxygen $\left(\mathrm{H}_{2} \mathrm{O}_{2}, \mathrm{OH}^{*}\right.$, and $\mathrm{O}_{2}^{-}$), many strict anaerobes as well as aerobic organisms contain antioxidant enzymes. The most important of these are catalase and superoxide dismutase (SOD). SOD removes free superoxide radicals that arise during the one-electron reduction of $\mathrm{O}_{2}$, catalyzing the dismutation reaction of $\mathrm{O}_{2}^{-}$, yielding $\mathrm{H}_{2} \mathrm{O}_{2}$ and $\mathrm{O}_{2}$. Hydrogen peroxide acts as a reductant of the enzyme at low concentrations and as a reversible inactivator at high concentrations. The reaction mechanism includes alternating reduction and reoxidation of the metal in the active site of the SOD during consecutive interactions with $\mathrm{O}_{\dot{2}}^{-}$ [8].

The detection of SOD in obligate anaerobes raised a question concerning its function and origin in these organisms. Apparently, the main physiological role of SOD in anaerobic microorganisms as well as in aerobes is the prevention of cell damage caused by oxygen by neutralizing superoxide radicals. The latter may arise due to a transient exposure of the anaerobic cells to the air during the reaction of $\mathrm{O}_{2}$ with reduced flavins, catecholamines, quinones, iron- and sulfur-containing proteins, as well as under the action of mutagens and UV radiation [9]. It has been shown that strictly anaerobic microorganisms possessing significant SOD activity exhibit moderate or high 
oxygen tolerance compared to species that are deficient in this enzyme [10].

Superoxide dismutase contains metal ions as the prosthetic group in the active site. Depending on the metal, SODs are subdivided into four classes: $\mathrm{Cu} / \mathrm{Zn}-$, $\mathrm{Fe}-, \mathrm{Mn}-$, and Ni-containing enzymes. Most known SODs are homodimers, each subunit containing one metal ion, one disulfide bond, one sulfhydryl group, and a terminal acetylated amino group [11]. Fe- and $\mathrm{Mn}$ containing SODs exhibit significant similarity in their amino acid sequences and tertiary structures [12]. However, the bacterial $\mathrm{Mn}$ - and Fe-containing SODs are more similar to each other than to the corresponding enzymes of Archaea, which suggests that the common features in the amino acid sequences are rather connected with evolutionary relations than with the presence of a specific metal as the cofactor [13]. However, SODs belonging to these two classes differ in their sensitivity to sodium azide: $1 \mathrm{mM} \mathrm{NaN}_{3}$ inhibits Fe-containing SODs by $70-90 \%$, while Mn-containing SODs lose only $50 \%$ of their activity in the presence of $20 \mathrm{mM} \mathrm{NaN}_{3}$ [14]. Hydrogen peroxide irreversibly inactivates $\mathrm{Cu} / \mathrm{Zn}$ - and $\mathrm{Fe}$-containing SODs [11], but does not affect Mn-containing SOD (the enzyme retains its activity for at least $2 \mathrm{~h}$ in the presence of $5 \mathrm{mM} \mathrm{H} \mathrm{H}_{2}$ ). Mn- and Fe-containing SODs can be divided into two subclasses: the enzymes of the first subclass require the presence of a specific metal in the active site for their activity, while the SODs of the second subclass (cambialistic SODs) exhibit their activity in the presence of either Fe and Mn ions that bind to the same active site [15].

It was long thought that the methanogenic Archaea possess neither SOD nor catalase. Later, low SOD activity was revealed in Methanobacterium bryantii and in some representatives of Methanomicrobiales [16]. Investigation of SOD in these microorganisms extremely sensitive to the presence of oxygen was further continued. Now SOD has been isolated from M. bryantii [16], M. thermoautotrophicum [13], and M. barkeri strain Fusaro [17]. It was assumed that the SOD from M. bryantii is an evolutionary ancestor of the related $\mathrm{Fe}$ - and $\mathrm{Mn}$-containing prokaryotic SODs [16]. However, a sod gene was not revealed in the genome of Methanococcus jannaschii [18] and Archaeoglobus fulgidus (sulfate reducing bacterium that is phylogenetically related to Methanosarcinaceae) [19]. Previously, we purified and characterized a heme-containing catalase from M. arboriphilus strain AZ [20]. In this microorganism, a rather high for anaerobic organism SOD activity was revealed $(22 \mathrm{U} / \mathrm{mg})$. The maximal SOD activity was observed in the stationary growth phase, where the rate of cell death is high and the formation of $\mathrm{O}_{\dot{2}}^{-}$is possible. This value exceeded fivefold the activity in the middle of the exponential growth phase [21]. In the present work, we describe the method of purification of SOD from this microorganism and characterize the properties of the purified enzyme.

\section{MATERIALS AND METHODS}

Microorganism and conditions of cultivation. In this work we used the methanogenic archaeon Methanobrevibacter arboriphilus strain AZ (DSMZ 744) from the collection of DSMZ (Deutsche Sammlung von Mikroorganismen und Zellkulturen GmbH, Germany).

The microorganism was cultivated in the medium described earlier [22] with some modifications. The medium (1 liter) contained $0.75 \mathrm{~g} \mathrm{KH}_{2} \mathrm{PO}_{4}, 0.75 \mathrm{~g}$ $\mathrm{K}_{2} \mathrm{HPO}_{4}, 1.0 \mathrm{~g} \mathrm{NH} \mathrm{N}_{4} \mathrm{Cl}, 0.36 \mathrm{~g} \mathrm{MgCl}_{2} \cdot 6 \mathrm{H}_{2} \mathrm{O}, 0.28 \mathrm{~g}$ $\mathrm{Na}_{2} \mathrm{~S} \cdot 9 \mathrm{H}_{2} \mathrm{O}, 0.001 \mathrm{~g}$ resazurin, $10 \mathrm{ml}$ of trace element solution SL-10 $+\mathrm{Ca}^{2+}, 10 \mathrm{ml}$ of vitamin solution, $4.8 \mathrm{~g}$ $\mathrm{NaHCO}_{3}, 1.0 \mathrm{~g}$ of yeast extract (Serva, USA), and $0.5 \mathrm{~g}$ of $\mathrm{L}$-cysteine- $\mathrm{HCl}$. The trace element solution SL-10 + $\mathrm{Ca}^{2+}$ (1 liter) contained $1.5 \mathrm{~g} \mathrm{FeCl}_{2} \cdot \mathrm{H}_{2} \mathrm{O}$ dissolved in $10 \mathrm{ml}$ of $25 \% \mathrm{HCl}, 70 \mathrm{mg} \mathrm{ZnCl}, 100 \mathrm{mg} \mathrm{MnCl} \cdot 4 \mathrm{H}_{2} \mathrm{O}$, $6 \mathrm{mg} \mathrm{H}_{3} \mathrm{BO}_{3}, 190 \mathrm{mg} \mathrm{CoCl} \cdot 6 \mathrm{H}_{2} \mathrm{O}, 2 \mathrm{mg} \mathrm{CuCl} \mathrm{Cu}_{2} \cdot 2 \mathrm{H}_{2} \mathrm{O}$, $24 \mathrm{mg} \mathrm{NiCl} \cdot \cdot 6 \mathrm{H}_{2} \mathrm{O}, 36 \mathrm{mg} \mathrm{Na} \mathrm{MoO}_{4} \cdot 2 \mathrm{H}_{2} \mathrm{O}$, and $20 \mathrm{mg}$ $\mathrm{CaCl}_{2}$. The vitamin solution (1 liter) contained $2 \mathrm{mg}$ biotin, $2 \mathrm{mg}$ folic acid, $10 \mathrm{mg}$ pyridoxine hydrochloride, $5 \mathrm{mg}$ thiamine hydrochloride, $5 \mathrm{mg}$ riboflavin, $5 \mathrm{mg}$ nicotinic acid, $5 \mathrm{mg}$ Ca-DL-pantothenate, $0.1 \mathrm{mg} \mathrm{B}_{12}, 5 \mathrm{mg}$ $p$-aminobenzoic acid, and $5 \mathrm{mg}$ lipoic acid. The final $\mathrm{pH}$ of the medium was 7.0-7.5. Stock solutions of $\mathrm{MgCl}_{2} \cdot 6 \mathrm{H}_{2} \mathrm{O}$ and $\mathrm{Na}_{2} \mathrm{~S} \cdot 9 \mathrm{H}_{2} \mathrm{O}$ were sterilized separately.

Methanobrevibacter arboriphilus strain AZ growing autotrophically under $\mathrm{H}_{2} / \mathrm{CO}_{2}$ mixture $(80: 20, \%)$ was cultivated in 0.5 - and 2-liter flasks half-filled with the medium and plugged by rubber stoppers that were held with aluminum or plastic caps. The nutrient medium and all necessary solutions were prepared before the autoclaving under anaerobic conditions according to Hungate technique [23], alternating triply the pumping out of the vessel with its filling with $\mathrm{N}_{2}$ under pressure. The microorganism was cultivated at $37^{\circ} \mathrm{C}$ and $150 \mathrm{rpm}$. The $\mathrm{H}_{2} / \mathrm{CO}_{2}$ gas phase was changed daily (final pressure of $1.4 \mathrm{~atm})$.

The volume of the inoculum material constituted $10 \%$. All the procedures connected with the reinoculation or introduction of supplements to the medium were performed under anaerobic conditions using sterile syringes. When necessary, the nutrient medium was supplemented with $20 \mathrm{mM}$ sterile solution (sterilized by filtration) of paraquat (methyl viologen, Sigma-Aldrich, Germany).

The amount of biomass was determined turbidimetrically using a spectrophotometer (Amersham Pharmacia Biotech, Sweden) at $578 \mathrm{~nm}$ in $1-\mathrm{cm}$ pathlength plastic cuvettes.

Purification of SOD. Cells of M. arboriphilus strain AZ were collected in the late exponential growth phase ( $1 \mathrm{~g}$ wet biomass/liter) and washed free from the medium by centrifugation $\left(9000 \mathrm{~g}, 20 \mathrm{~min}, 4^{\circ} \mathrm{C}\right)$ in $50 \mathrm{mM}$ potassium-phosphate buffer, $\mathrm{pH}$ 7.0. Then $8 \mathrm{~g}$ of wet biomass was resuspended in $10 \mathrm{ml}$ of the same buffer. The cells were frozen $\left(-20^{\circ} \mathrm{C}\right)$ and destroyed by extrusion using an 
$\mathrm{X}$-press under the extensive pressure of $10 \mathrm{ton} / \mathrm{cm}^{2}$ with an X25 chamber for destruction (AB Biox, Sweden). The cell fragments were removed by centrifugation $(25,000 \mathrm{~g}$, $20 \mathrm{~min}, 4^{\circ} \mathrm{C}$ ). The cell extract was fractionated by ultracentrifugation $\left(240,000 \mathrm{~g}, 60 \mathrm{~min}, 4^{\circ} \mathrm{C}\right)$. The membrane and cytosolic fractions were assayed for the SOD activity and the protein content.

The extract was supplemented with $\left(\mathrm{NH}_{4}\right)_{2} \mathrm{SO}_{4}$ to $70 \%$ saturation. After $10 \mathrm{~min}$ of incubation at $0^{\circ} \mathrm{C}$, the suspension was centrifuged $\left(25,000 \mathrm{~g}, 15 \mathrm{~min}, 4^{\circ} \mathrm{C}\right)$, and the supernatant was supplemented with $\left(\mathrm{NH}_{4}\right)_{2} \mathrm{SO}_{4}$ to $100 \%$ saturation. After $10 \mathrm{~min}$ of incubation at $0^{\circ} \mathrm{C}$, the suspension was centrifuged $\left(25,000 \mathrm{~g}, 15 \mathrm{~min}, 4^{\circ} \mathrm{C}\right)$ and the pellet was collected.

The subsequent purification was performed using column chromatography on an FPLC system (Amersham Pharmacia Biotech). All buffer and eluting salt solutions were filtered and degassed before use. The precipitate of 70-100\% ammonium sulfate saturation was dissolved in $50 \mathrm{mM}$ Mops- $\mathrm{KOH}, \mathrm{pH}$ 7.0, containing $1 \mathrm{M}$ ammonium sulfate, and the solution was applied to a 5-ml CL-4B phenyl-Sepharose column (Amersham Pharmacia Biotech) equilibrated with $50 \mathrm{mM}$ Mops-KOH, pH 7.0, containing $1 \mathrm{M}$ ammonium sulfate. The SOD was eluted with $60 \mathrm{ml}$ of 1-0 M linear gradient of ammonium sulfate (flow rate $0.75 \mathrm{ml} / \mathrm{min}$, fraction volume $1 \mathrm{ml}$ ). The activity of SOD was found in the fractions eluted at 0.78 $0.52 \mathrm{M}\left(\mathrm{NH}_{4}\right)_{2} \mathrm{SO}_{4}$. The fractions containing SOD were pooled and dialyzed against $50 \mathrm{mM}$ Mops- $\mathrm{KOH}, \mathrm{pH} 7.0$, at $4^{\circ} \mathrm{C}$. The dialyzate was applied to a 5-ml Source Q Fast Flow column (Amersham Pharmacia Biotech) equilibrated with $50 \mathrm{mM}$ Mops-KOH, pH 7.0. The SOD was eluted with $60 \mathrm{ml}$ of $0-1 \mathrm{M}$ linear $\mathrm{NaCl}$ gradient (flow rate $0.5 \mathrm{ml} / \mathrm{min}$, fraction volume $1 \mathrm{ml}$ ). The SOD activity was found in the fractions eluted at $0.46-0.54 \mathrm{M} \mathrm{NaCl}$. The fractions were pooled and diluted with $50 \mathrm{mM}$ potassiumphosphate buffer, $\mathrm{pH}$ 7.0. The resulting solution was applied to a 1-ml ceramic hydroxyapatite column (BioRad, USA) equilibrated with $50 \mathrm{mM}$ potassium-phosphate buffer, $\mathrm{pH}$ 7.0. The SOD was eluted with $20 \mathrm{ml}$ of $50-500 \mathrm{mM}$ linear gradient of potassium phosphate (flow rate $1 \mathrm{ml} / \mathrm{min}$, fraction volume $0.4 \mathrm{ml}$ ). The activity of SOD was found in the fractions eluted at $0.23-0.25 \mathrm{M}$ potassium phosphate. The fractions were pooled and concentrated using a $30 \mathrm{kD}$ Centricon membrane (Millipore, USA) by centrifugation $(13,000 \mathrm{~g})$. The preparation of the purified SOD was stored at $4^{\circ} \mathrm{C}$.

Assay of SOD activity. The activity of SOD was determined spectrophotometrically at $25^{\circ} \mathrm{C}$ using the xanthine oxidase/cytochrome $c$ method [24]. The reaction mixture $(0.7 \mathrm{ml})$ contained: $50 \mathrm{mM}$ potassium phosphate buffer, $\mathrm{pH}$ 7.8, $0.1 \mathrm{mM}$ EDTA, $50 \mu \mathrm{M}$ xanthine (sodium salt, Sigma-Aldrich), $1.7 \mathrm{mU}$ of xanthine oxidase (Sigma-Aldrich), $10 \mu \mathrm{M}$ cytochrome $c$ (Merck, Germany), and when necessary, inhibitors of SOD (2$10 \mathrm{mM}$ potassium cyanide or $2-10 \mathrm{mM}$ sodium azide).
The action of the inhibitors was tested using preparations of Fe- and Mn-containing SODs from E. coli (SigmaAldrich, specific activity of 3070 and $4400 \mathrm{U} / \mathrm{mg}$, respectively). The reduction of cytochrome $c$ by the superoxide anion formed due to the reduction of $\mathrm{O}_{2}$ in the reaction with xanthine was monitored by an increase in the absorption at $550 \mathrm{~nm}$. The amount of the enzyme that was required to inhibit the reduction of cytochrome $c$ by $50 \%$ was taken as the unit of the SOD activity.

Protein concentration was determined by the Bradford method [25] using BSA (Sigma-Aldrich) dried to constant weight as the standard.

SDS-polyacrylamide gel electrophoresis. A sample for SDS-PAGE contained $20 \mu \mathrm{l}$ of a protein preparation (1-5 $\mu$ g protein) mixed with $5 \mu \mathrm{l}$ of SDS-buffer solution (2\% SDS, $10 \%$ glycerol, $62 \mathrm{mM}$ Tris- $\mathrm{HCl}, 50 \mathrm{mM}$ dithiothreitol, pH 6.8). Before the application to a gel, samples were incubated at $90^{\circ} \mathrm{C}$ for $5 \mathrm{~min}$. The resolving $10 \%$ gel $(5 \mathrm{ml})$ contained $1.88 \mathrm{ml}$ of $1 \mathrm{M}$ Tris- $\mathrm{HCl}$ buffer, $\mathrm{pH} 8.8$, $0.05 \mathrm{ml}$ of $10 \%$ SDS solution, $1.36 \mathrm{ml}$ of $\mathrm{H}_{2} \mathrm{O}, 1.67 \mathrm{ml}$ of $30 \%$ acrylamide/bis-acrylamide $(29: 1)$ solution (Sigma), $0.05 \mathrm{ml}$ of $10 \%$ ammonium persulfate (Merck), and $4 \mu$ of TEMED (N,N, $N^{\prime}, N^{\prime}$-tetramethylethylenediamine; Amersham Pharmacia Biotech). The concentrating $5 \%$ gel $(2 \mathrm{ml})$ contained $0.25 \mathrm{ml} 1 \mathrm{M}$ Tris- $\mathrm{HCl}$ buffer, $\mathrm{pH} 6.8,20 \mu \mathrm{l}$ of $10 \%$ SDS solution, $1.36 \mathrm{ml}$ of $\mathrm{H}_{2} \mathrm{O}$, $0.33 \mathrm{ml}$ of $30 \%$ acrylamide/bis-acrylamide $(29: 1)$ solution, $20 \mu \mathrm{l}$ of $10 \%$ ammonium persulfate, and $2 \mu \mathrm{l}$ of TEMED.

A solution of proteins of 14-94 kD (Low Molecular Weight Calibration Kit, Amersham Pharmacia Biotech) was used as the standard. Electrophoresis was performed at $170 \mathrm{~V}$ using a Power Pac 300 unit (Bio-Rad).

After the electrophoresis, the gel was placed into $20 \mathrm{ml}$ of a staining solution ( $1 \mathrm{~g}$ of Coomassie Blue R-250 (Sigma-Aldrich), $450 \mathrm{ml}$ of methanol, $450 \mathrm{ml}$ of water, and $100 \mathrm{ml}$ of glacial acetic acid), heated for 20-60 sec in a microwave oven, and then incubated for 30 min under gentle agitation. The background staining was removed by boiling in water for $5 \mathrm{~min}$.

Determination of molecular weight of the SOD by gel filtration. The molecular weight of the purified SOD was determined on a Superdex 200 gel-filtration column $(1 \times$ $30 \mathrm{~cm}$ ) using an FPLC system (Amersham Pharmacia Biotech). The column was equilibrated with $100 \mathrm{mM}$ potassium phosphate buffer, $\mathrm{pH}$ 7.0, and calibrated with the following protein standards: ferritin $(440 \mathrm{kD})$, bovine liver catalase $(232 \mathrm{kD})$, aldolase $(158 \mathrm{kD})$, ovalbumin (43 kD), and RNase A (13.7 kD) (Amersham Pharmacia Biotech).

Atomic absorption and mass spectroscopies. The metal content in the preparation of the purified SOD was preliminarily determined using inductively coupled plasma mass spectroscopy (Element 2 ThermoFinnigan, USA). The content of $\mathrm{Fe}$ in the active site of SOD was determined using a $5100 \mathrm{ZL}$ atomic absorption graphite 
analyzing spectrophotometer (Perkin Elmer, USA) with Zeeman background correction, hollow spectral cathode lamps (Perkin Elmer), and graphite tubes. An investigated preparation $(20 \mu \mathrm{l})$ or calibrating standard (cytochrome $c$ solutions of different concentration) was applied into the graphite tube of the analyzer. The precise value of the molecular weight of the enzyme was determined on a Bruker Reflex III MALDI-TOF mass spectrometer (Bruker Daltonics GmbH, Germany) under linear mode of measurements using samples supplemented with trypsinogen as the internal standard. To prepare the sample, $1 \mu \mathrm{l}$ of $1 \mu \mathrm{M}$ solution of the purified SOD was mixed with $9 \mu$ of a matrix solution, applied to the surface of the target, and dried at room temperature. The matrix solution was a saturated solution of synapinic acid in a mixture of methanol, acetonitrile, and acetone (50:25:25, v/v) supplemented with $0.1 \%$ trifluoroacetic acid. The mass spectrum of the protein was an average signal of 300 laser pulses.

\section{RESULTS}

The SOD activity in the extract of the cells of $M$. arboriphilus strain $\mathrm{AZ}$ on the middle phase of the exponential growth of the culture constituted approximately

Table 1. Localization of SOD in cells of M. arboriphilus strain AZ

\begin{tabular}{l|c|c}
\hline \multirow{2}{*}{ Fraction } & \multicolumn{2}{|c}{$\begin{array}{c}\text { Total activity } \\
\text { of the enzyme }\end{array}$} \\
\cline { 2 - 3 } & units & $\%$ \\
\hline $\begin{array}{l}\text { Original cell extract } \\
(25,000 g)\end{array}$ & 8200 & 100.0 \\
$\begin{array}{l}\text { Soluble fraction } \\
(240,000 g)\end{array}$ & 7700 & 93.9 \\
$\begin{array}{l}\text { Structural components } \\
\text { of the cells }(240,000 g)\end{array}$ & 344 & 4.2 \\
\hline
\end{tabular}

$22 \mathrm{U} / \mathrm{mg}$, which was determined by the xanthine oxidase-cytochrome $c$ method.

To determine the localization of SOD in the cells, cell extract was fractionated by ultracentrifugation at $240,000 \mathrm{~g}$. The total activity found in the soluble fraction constituted more than $90 \%$ of the SOD activity determined in the extract (Table 1). The extract retained the SOD activity in the presence of oxygen, and thus the enzyme could be purified under aerobic conditions.

Superoxide dismutase was isolated from $M$. arboriphilus strain $\mathrm{AZ}$ cells in four steps with rather high yield of $22 \%$, the extent of purification being 190 . The results of the purification are presented in Table 2 . The preparation of SOD $(0.43 \mathrm{mg}$, specific activity $3970 \mathrm{U} / \mathrm{mg})$ was obtained from the cell extract containing $370 \mathrm{mg}$ of total protein. The preparation of SOD, as well as the cell extract before and after ultracentrifugation, retained the specific activity for at least 70 days at $-20^{\circ} \mathrm{C}$ or for 10 days at $4^{\circ} \mathrm{C}$.

SDS-PAGE of the purified SOD yielded a single band at $23 \mathrm{kD}$ (Fig. 1b). After boiling of the purified protein in the presence of SDS for $5 \mathrm{~min}$, SDS-PAGE of the preparation resulted in two bands of 23 and $80 \mathrm{kD}$. After boiling of the purified protein in the presence of SDS for $15-20 \mathrm{~min}$, the protein band corresponding to $80 \mathrm{kD}$ disappeared, and the intensity of the $23-\mathrm{kD}$ band significantly increased. After gel filtration on Superdex 200, the SOD activity was found in the fraction corresponding to $80 \mathrm{kD}$ (Fig. 1a). The MALDI-TOF spectroscopy allowed determination of the precise molecular weight of the enzyme subunit-21,192 daltons.

In most cases, in cells of anaerobic microorganisms SOD is a Fe-containing enzyme. Assay for the metals in the active site of SOD from M. arboriphilus strain AZ revealed $1.1 \mathrm{~mol} F$ per mol subunit and only traces of Mn $(<0.1$ mol per mol subunit).

We investigated the effect of classic inhibitors of SOD, as well as hydrogen peroxide, on the activity of the SOD purified from $M$. arboriphilus. The enzyme is inhibited by azide (but not cyanide) and inactivated by hydrogen peroxide. The concentration of $\mathrm{NaN}_{3}$ required for $50 \%$ inhibition of the SOD activity was $13.5 \mathrm{mM}$ (Fig. 2a). In the presence of $0.5 \mathrm{mM} \mathrm{H}_{2} \mathrm{O}_{2}$, the SOD from $M$.

Table 2. Purification of SOD from M. arboriphilus strain AZ

\begin{tabular}{|c|c|c|c|c|}
\hline Fraction & Protein, mg & Specific activity, U/mg & Purification extent & Yield, \% \\
\hline Supernatant $240,000 \mathrm{~g}$ & 370 & 21 & 1 & 100 \\
\hline $70-100 \%\left(\mathrm{NH}_{4}\right)_{2} \mathrm{SO}_{4}$ & 115 & 65 & 3 & 96 \\
\hline Phenyl-Sepharose & 13.0 & 357 & 17 & 60 \\
\hline Source Q & 1.4 & 1780 & 85 & 32 \\
\hline Hydroxyapatite & 0.43 & 3970 & 189 & 22 \\
\hline
\end{tabular}




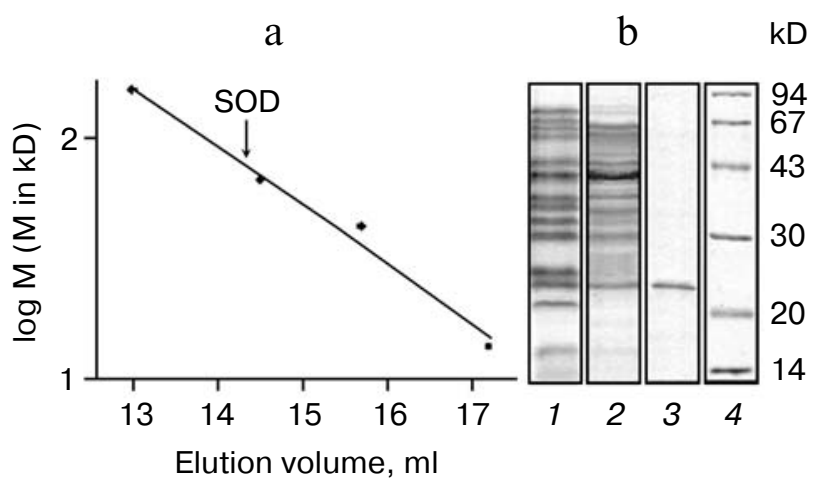

Fig. 1. Characteristics of the purified SOD from M. arboriphilus strain AZ. a) Gel filtration on a Superdex 200 column. The column was calibrated with four standard proteins $(158,67,43$, and $13.7 \mathrm{kD})$. The elution volume of SOD is indicated by the arrow. b) SDS-PAGE: 1) original cell extract; 2) after phenylSepharose; 3) after hydroxyapatite; 4) protein standards.

arboriphilus lost $50 \%$ of its activity after $60 \mathrm{~min}$ of incubation at $24^{\circ} \mathrm{C}$ (Fig. 2b).

To investigate the ability of $M$. arboriphilus strain AZ exhibiting a rather high for a strict anaerobe SOD activity to maintain viability under conditions of oxidative stress, we performed the following experiment. The microorganism was cultivated under standard conditions for $24 \mathrm{~h}$, and then the medium was supplemented with a sterile paraquat solution of necessary concentration. Paraquat has the redox potential of $-446 \mathrm{mV}$ and it is a source of superoxide radicals. After equal time intervals, the turbidity of the cell suspension was measured and the effect of paraquat on the cell growth was estimated (Fig. 3 ). The addition of $0.2-0.8 \mathrm{mM}$ paraquat decreased sig- nificantly the yield of the biomass and resulted in a change in the growth curve shape. At the concentration of $1.0 \mathrm{mM}$, the growth of the archaeon was completely suppressed.

\section{DISCUSSION}

The preparation of SOD purified from M. arboriphilus strain $\mathrm{AZ}$ exhibited a rather high specific activity (3970 U/mg) compared to other methanogens: the specific activity of SOD from $M$. bryantii constituted $2060 \mathrm{U} / \mathrm{mg}$ [16], the activity of SOD from M. barkeri strain Fusaro was $1500 \mathrm{U} / \mathrm{mg}$ [17], and SOD from $M$. thermoautotrophicum exhibited $855 \mathrm{U} / \mathrm{mg}$ [13]. The described SODs from methanogenic Archaea are also localized in the soluble cell fraction and stable under aerobic conditions.

The data on the molecular weight of the enzyme indicate that the SOD from M. arboriphilus strain AZ is a homotetramer with the subunit of $21.2 \mathrm{kD}$. Superoxide dismutases from M. bryantii [16] and M. thermoautotrophicum [13] are also homotetramers, but they are composed of the subunits of 26 and $24 \mathrm{kD}$, respectively. The molecular weight of the SOD from M. barkeri strain Fusaro is $25 \mathrm{kD}$ [17]. During long-term boiling with SDS, the SOD holoenzyme from $M$. arboriphilus dissociates into subunits. This was also demonstrated for the Fe-containing SOD from M. barkeri strain Fusaro [17] and for the Fecontaining SOD with the noncovalently associated subunits from M. bryantii. The latter enzyme exhibited a particular high stability, since dialysis against $2 \%$ SDS in $0.125 \mathrm{M}$ Tris- $\mathrm{HCl}, \mathrm{pH}$ 6.8, for $18 \mathrm{~h}$, as well as 2-min boiling in the presence of $6 \mathrm{M}$ guanidine chloride with the a

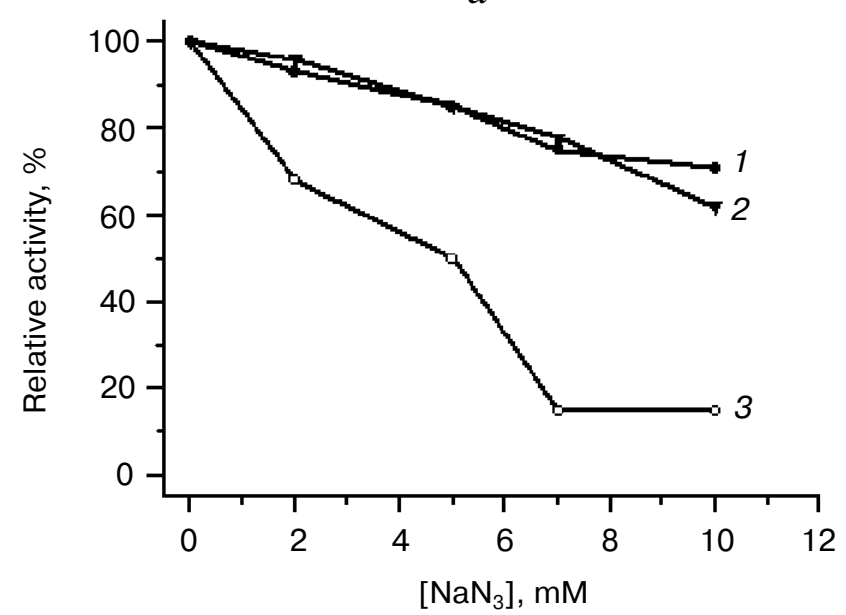

b

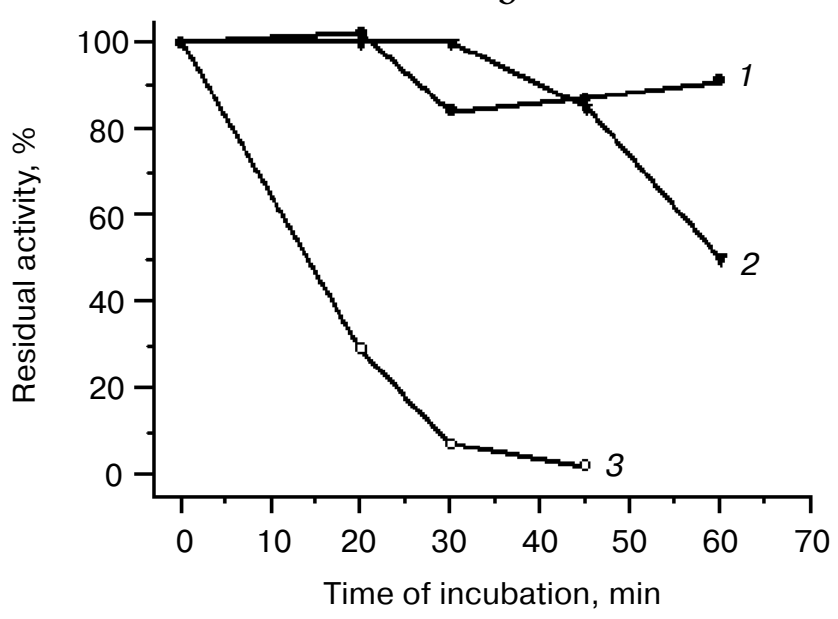

Fig. 2. Properties of SODs from E. coli and M. arboriphilus strain AZ. a) Inhibition of SOD by sodium azide; b) inactivation of SOD in the presence of $0.5 \mathrm{mM}$ hydrogen peroxide: 1) Mn-containing SOD from E. coli; 2) Fe-containing SOD from M. arboriphilus strain AZ; 3) Fecontaining SOD from E. coli. 


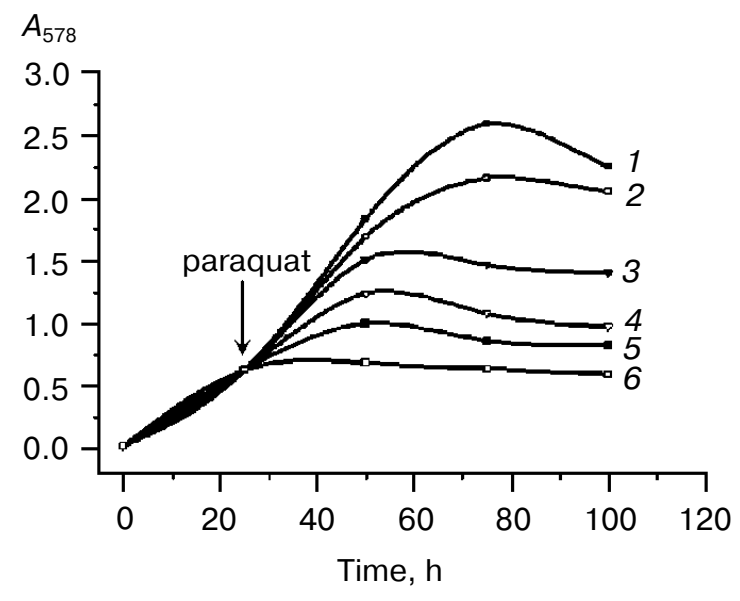

Fig. 3. Effect of paraquat on the growth of $M$. arboriphilus strain AZ: 1 ) in the absence of paraquat; 2-6) in the presence of 100 , $200,400,800$, and $1000 \mu \mathrm{M}$ paraquat, respectively. Paraquat was added to the nutrient medium after $24 \mathrm{~h}$ of the cultivation of the microorganism.

SOD. Such intermediate (between Fe- and Mn-SODs) in terms of the amino acid sequences Fe-containing SODs remained little sensitive to hydrogen peroxide [13].

Extracts of the cells of M. arboriphilus strain AZ from the middle phase of the exponential growth contain SOD with specific activity that is twofold higher than the extracts of M. barkeri strain Fusaro [17]. The cells of $M$. arboriphilus strain $\mathrm{AZ}$ are less sensitive to paraquat than $M$. barkeri strain Fusaro, which is in agreement with the statement concerning the correlation between the SOD activity and the tolerance of air.

The authors are grateful to Dr. A. Ammann and Dr. D. Kistler for their help in the analytic experiments. A Bruker Reflex III MALDI-TOF spectrometer was generously supplied by Novartis (Switzerland). This work was supported by an INTAS grant (YSF 03-55-1667) to A. Brioukhanov. V. Nesatyy is grateful for the support of his work by the Swiss department of the VELUX Fund.

\section{REFERENCES}

subsequent analogous dialysis resulted only in the partial dissociation of the enzyme [16].

Like other SODs from anaerobic microorganisms, the SOD from $M$. arboriphilus is an Fe-containing enzyme, which was demonstrated using atomic absorption and mass spectroscopies. The content of Fe in the active site of the enzyme corresponds to that found in other known Fe-containing SODs.

It was shown that SOD from $M$. arboriphilus strain AZ is inhibited by azide (but not cyanide) and inactivated by hydrogen peroxide. This also indicates that the enzyme is a $\mathrm{Fe}$-containing SOD. However, in comparison with $\mathrm{Fe}-$ containing SOD from E. coli (Sigma), Fe-containing SOD from $M$. arboriphilus strain AZ is much more resistant to $\mathrm{NaN}_{3}$ and $\mathrm{H}_{2} \mathrm{O}_{2}$ (Fig. 2). The concentration of sodium azide that is required to inhibit the enzyme by $50 \%$ ([I $]_{0.5}$ ) constituted $13.5 \mathrm{mM}$ for SOD from M. arboriphilus strain AZ, 10 mM for SOD from M. barkeri strain Fusaro [17], and $15 \mathrm{mM}$ for the SOD from M. bryantii [16]. The character of the inactivation of SOD from M. arboriphilus strain $\mathrm{AZ}$ by $\mathrm{H}_{2} \mathrm{O}_{2}$ virtually completely coincides with that of the enzyme from M. barkeri strain Fusaro. The enzyme from M. thermoautotrophicum is one of the Fe-containing SODs exhibiting a high resistance to $\mathrm{H}_{2} \mathrm{O}_{2}$. It retains its activity after $24 \mathrm{~h}$ of incubation in the presence of $0.5 \mathrm{mM}$ $\mathrm{H}_{2} \mathrm{O}_{2}$ [13]. Thus, the Fe-containing SODs from methanogenic Archaea differ from the known bacterial $\mathrm{Fe}$-containing SODs in the character of their inhibition and inactivation. Considering that the described properties of SODs from Archaea were earlier attributed to Mncontaining SODs, we hypothesize that some strictly anaerobic Archaea that adapted to aerobiosis due to the presence of $\mathrm{H}_{2} \mathrm{O}_{2}$-resistant $\mathrm{Mn}$-containing SOD created again the Fe-containing enzyme from Mn-containing
1. Kiener, A., and Leisinger, T. (1983) Syst. Appl. Microbiol., 4, 305-312.

2. Leadbetter, J. R., and Breznak, J. A. (1996) Appl. Environ. Microbiol., 62, 3620-3631.

3. Zeikus, J. G., and Henning, D. L. (1975) Antonie Van Leeuwenhoek, 41, 543-552.

4. Brusa, T., Ferrari, F., and Ganzi, E. (1998) J. Basic. Microbiol., 38, 79-84.

5. Fetzer, S., Bak, F., and Conrad, R. (1993) FEMS Microbiol. Ecol., 12, 107-115.

6. Peters, V., and Conrad, R. (1995) Appl. Environ. Microbiol., 61, 1673-1676.

7. Wagner, D., Pfeiffer, E.-M., and Bock, E. (1999) Soil Biol. Biochem., 31, 999-1006.

8. Fridovich, I. (1995) Annu. Rev. Biochem., 64, 97-112. Biology of Antioxidant Defenses (Scandalios, J. G., ed.) Cold Spring Harbor Laboratory, Cold Spring Harbor, N. Y., pp. 447-493.

10. Gregory, E. M., and Dapper, C. H. (1980) J. Bacteriol., 144, 967-974.

11. Bannister, J. V., Bannister, W. H., and Rotilio, G. (1987) CRC Crit. Rev. Biochem., 22, 111-180.

12. Parker, M. W., and Blake, C. C. F. (1988) FEBS Lett., 229, 377-382.

13. Takao, M., Yasui, A., and Oikawa, A. (1991) J. Biol. Chem., 266, 14151-14154.

14. Misra, H. P., and Fridovich, I. (1978) Arch. Biochem. Biophys., 189, 317-322.

15. Meier, B., Barra, D., Bossa, I. F., Calabrese, L., and Rotilio, G. (1982) J. Biol. Chem., 257, 13977-13980.

16. Kirby, T. W., Lancaster, J. R., and Fridovich, I. (1981) Arch. Biochem. Biophys., 210, 140-148.

17. Brioukhanov, A., Netrusov, A., Sordel, M., Thauer, R. K., and Shima, S. (2000) Arch. Microbiol., 174, 213-216.

18. Bult, C. J., White, O., Olsen, G. J., Zhou, L., Fleischmann, R. D., Sutton, G. G., Blake, J. A.,
9. Touati, D. (1997) in Oxidative Stress and the Molecular 
FitzGerald, L. M., Clayton, R. A., Gocayne, J. D., Kerlavage, A. R., Dougherty, B. A., Tomb, J. F., Adams, M. D., Reich, C. I., Overbeek, R., Kirkness, E. F., Weinstock, K. G., Merrick, J. M., Glodek, A., Scott, J. L., Geoghagen, N. S., and Venter, J. C. (1996) Science, 273, 1058-1073.

19. Klenk, H. P., Clayton, R. A., Tomb, J. F., White, O., Nelson, K. E., Ketchum, K. A., Dodson, R. J., Gwinn, M., Hickey, E. K., Peterson, J. D., Richardson, D. L., Kerlavage, A. R., Graham, D. E., Kyrpides, N. C., Fleischmann, R. D., Quackenbush, J., Lee, N. H., Sutton, G. G., Gill, S., Kirkness, E. F., Dougherty, B. A., McKenney, K., Adams, M. D., Loftus, B., Peterson, S., Reich, C. I., McNeil, L. K., Badger, J. H., Glodek, A., Zhou, L., Overbeek, R., Gocayne, J. D., Weidman, J. F., McDonald, L., Utterback, T., Cotton, M. D., Spriggs, T.,
Artiach, P., Kaine, B. P., Sykes, S. M., Sadow, P. W., D’Andrea, K. P., Bowman, C., Fujii, C., Garland, S. A., Mason, T. M., Olsen, G. J., Fraser, C. M., Smith, H. O., Woese, C. R., and Venter, J. C. (1997) Nature, 390, 364-370.

20. Shima, S., Sordel-Klippert, M., Brioukhanov, A., Netrusov, A., Linder, D., and Thauer, R. K. (2001) Appl. Environ. Microbiol., 67, 3041-3045.

21. Brioukhanov, A. L., Thauer, R. K., and Netrusov, A. I. (2002) Mikrobiologiya, 71, 330-335.

22. Asakawa, S., Morii, H., Akagawa-Matsushita, M., Koga, Y., and Hayano, K. (1993) Int. J. Syst. Bacteriol., 43, 683686.

23. Bryant, M. P. (1972) Am. J. Clin. Nutr., 25, 1324-1328.

24. McCord, J. M., and Fridovich, I. (1969) J. Biol. Chem., 244, 6049-6055.

25. Bradford, M. M. (1976) Analyt. Biochem., 72, 248-254. 